\title{
Should Trypanosoma cruzi be Called "cruzi" Complex? A Review of the Parasite Diversity and the Potential of Selecting Population after in Vitro Culturing and Mice Infection
}

\author{
Rodolfo Devera, Octavio Fernandes/*, José Rodrigues Coura/ ${ }^{+}$
}

Departmento de Medicina Tropical, Instituto Oswaldo Cruz-Fiocruz, Av. Brasil 4365, 21045-900 Rio de Janeiro, RJ, Brasil

*Departamento de Patologia, Faculdade de Ciências Médicas, Uerj, Rio de Janeiro, RJ. Brasil

\begin{abstract}
Morpho-biological diversity of Trypanosoma cruzi has been known since Chagas' first works in 1909. Several further studies confirmed the morphological differences among the parasite strains, which were isolated from different reservoirs and vectors, as well as from human beings. In the early sixties, antigenic differences were found in the parasite strains from various sources. These differences, coupled to the observation of regional variations of the disease, led to the proposal of the term cruzi complex to designate the taxon T. cruzi. Since then this protozoan has been typed in distinct biodemes, zymodemes and lineages which were consensually grouped into T. cruzi I, T. cruzi II and into non-grouped strains. T. cruzi genotypic characterization, initially carried out by schizodeme analysis and more recently by various other techniques, has shown a great diversity of the parasite strains. In fact, T. cruzi is formed by groups of heterogeneous sub-population, which present specific characteristics, including distinct histotropism. The interaction of the different infecting clones of the cruzi complex and the human host will determine the morbidity of the disease.
\end{abstract}

Key words: Trypanosoma cruzi - "cruzi” complex - genetic diversity

Trypanosoma cruzi is a protozoan parasite presenting two alternating host during its life cycle: insect vectors of the Family Triatominae and vertebrates, including a wide variety of mammals. They are hemoflagellates of the Order Kinetoplastida harboring a differentiated mitochondria, the kinetoplast, corresponding to a DNA condensation located inside the single and branched organelle. (Hoare 1964).

The taxon is not composed by a homogeneous species. In the sixties, when the present molecular tools were not available, Coura et al. (1966) defended the use of the term "cruzi" complex to designate the protozoan, based on morphological variation, immunological features, distinct virulence and differences in the regional and individual pattern of Chagas disease (Coura 1966). Nowadays it is known that $T$. cruzi is an heterogeneous species consisting of several sub-populations of the parasite circulating among various wild and domestic vertebrates and invertebrate hosts (Morel et al. 1986, Zingales et al. 1998). Intra-specific variations among $T$. cruzi have been observed based on (i) the biological behavior of the strains in laboratory animals, (ii) biochemical features of the isolates, and (iii) molecular characteristics of the stocks (Bice \& Zeledón 1970, Petana \& Coura 1974, Miles et al. 1977, Melo \& Brener 1978, Morel et al. 1980, Andrade 1985, Araújo \& Chiari 1988, Carneiro et al. 1991, Macedo \& Pena

${ }^{+}$Corresponding author. Fax: +55-21-2280.3740. E-mail: coura@ioc.fiocruz.br

Received 24 June 2002

Accepted 25 September 2002
1998). In order to study the role of the parasite diversity in the pathogenesis of Chagas disease, a comprehensive characterization of the populations found in nature is crucial.

As T. cruzi is composed of heterogeneous populations, the same host may be simultaneously infected by different strains. In this scenario, a major concept is the clear existence of clones that are more representative, being found in several hosts in different geographic areas of Latin America (Tybarenc \& Brenière 1988, Lauria-Pires et al. 1996, 1977, Lauria-Pires \& Teixeira 1996, Andrade \& Campos 1998, Andrade 1999). Nowadays it is known that T. cruzi has a clonal population structure (Tibayrenc et al. 1986a, Tibayrenc \& Ayala 1988, 1991). This explains the existence of independent organisms with discrete biological features explaining the finding of a great number of clones in different geographic areas (Tibayrenc \& Brenière 1988).

Recent studies using molecular tools demonstrate that these major clones from endemic areas might be responsible for some clinical manifestations and chemotherapy response (Campos \& Andrade 1996, Andrade \& Campos 1998, Andrade 1999).

A current hypothesis suggests that the (i) heterogeneity and (ii) multiclonality of a strain determine differential tissue tropism and, consequently, variations in the clinical presentation of the disease (Andrade 1999). A correlation between the genetic diversity of $T$. cruzi and its pathogenicity was recently proposed as the clonal histotropic model that is based on the two aforementioned features (Macedo et al. 1992, Oliveira et al. 1998, 1999, Macedo \& Pena 1998).

In order to characterize a parasite strain using the current techniques, it is necessary to isolate $T$. cruzi through laboratory animal inoculation, xenodiagnosis and/or in vitro 
culture. These approaches can lead to the selection of a specific sub-population of the parasite that was present in the original inoculum, differing from those in the host's blood or tissue. Furthermore, due to the differential tropism of the various strains, the circulating clones and therefore available for haemoculture can be different from those that are causing the tissue lesion, supporting the clonal histotropic model of Chagas disease (Macedo \& Pena 1998). Some experimental evidence strengths this proposal (Andrade 1999) and it has been shown that clones in the cardiac tissue of some patients proved to be different from those in the esophagus. This means that different genotypes of $T$. cruzi present a favorite distribution in tissues of chronic chagasic patients, suggesting that the genetic variability of the parasite is one of the leading factors to the clinic form of the disease (Vago et al. 2000).

\section{WHY SHOULD WE CALL T. CRUZI AS T. CRUZI I AND $T$. CRUZI II?}

The genetic diversity of T. cruzi has been revealed by enzymatic markers (Miles et al. 1978, Miles 1983, Tibayrenc \& Ayala 1988), restriction fragment length polymorphism (RFLP) of the kinetoplast DNA (Morel et al. 1980), molecular karyotypes (Henrikson et al. 1993), DNA fingerprints (Macedo et al. 1992) and by randomly amplified polymorphic DNA analysis (RAPD) (Steindel et al. 1993, Tibayrenc et al. 1993). Alternatively, when markers derived from constitutive genes are used, such as the $24 \mathrm{~S} \alpha$ rRNA and the mini-exon genes, a different result is revealed. Based on these two targets, it has been observed that $T$. cruzi can be divided into two major well-defined groups that coincides with the isoenzymatic dichotomy proposed in the late seventies and corroborated in the nineties (Miles et al. 1977, 1980, Tibayrenc et al. 1993, Souto et al. 1996, Fernandes et al. 1998).

In the light of this dichotomy, $T$. cruzi strains are now classified into two major groups named T. cruzi I and $T$. cruzi II, denomination arisen from a consensus reached by specialists, who proposed the unification of the various classifications based on different markers (Anonymous 1999).

T. cruzi I is mainly observed in wild mammals and sylvan triatomines, whereas $T$. cruzi II is usually found in humans (Fernandes et al. 1998, Zingales et al. 1998). Fernandes et al. (1999a) revealed the presence of both groups in the sylvatic cycle of the parasite and the preferential association of $T$. cruzi major phylogenetic lineages with different hosts, illustrating the complexity of the parasite cycle in nature. These findings have helped to understand how the sylvatic and domestic cycles are connected and therefore, this new classification of $T$. cruzi has brought important contributions to the definition of the eco-epidemiology of Chagas disease.

\section{BIOLOGICAL DIVERSITY AND BIODEMES}

The proper characterization of a certain $T$. cruzi isolate is essential to determine the putative role that the different strains may play in the pathogenesis, geographic variation, clinical presentation and morbitity of Chagas disease and also in the distinct rates of cure after specific chemotherapy (WHO 1991).
Biological behavior in laboratory animals, mostly from the Family Muridae, is one of the parameters used to characterize the different strains of T. cruzi.

Although experiments conducted on T. cruzi infection in animal models do not faithfully reproduce the human infection, mouse has been widely used to study various aspects of the infection. The common use of this animal is justified by (i) the small size, (ii) large availability, (iii) easy maintenance, and (iv) simple manipulation. The mouse lineage also plays an important role and its choice depends on the type of the investigation being carried out. Different susceptibilities and survival rates are dependent of the mouse lineage and the used strain of the parasite (Andrade 2000, Araújo-Jorge 2000).

The vast majority of the biological characterizations of $T$. cruzi strains have been conducted on non-isogenic Swiss mice (Silva \& Nussenzweig 1953, Andrade et al. 1970, 1985, Mello \& Brener 1978, Andrade 1990). Swiss mouse belongs to an heterogeneous group and therefore should be considered the best representative of the characteristics of the human population from endemic areas. Nevertheless, other lineages have been used for characterization studies (Bice \& Zeledón 1970, Andrade et al. 1985, Araújo \& Chiari 1988, Oliveira et al. 1993). More recently, the use of isogenic lineages has been emphasized in order to obtain standard infections (Andrade 2000). However, those lineages are more used for immunopathological studies.

The biological behavior of $T$. cruzi strains is based on presented virulence and pathogenicity; thus, it is essential to define these concepts. Virulence is the capacity of the parasite to multiply inside a laboratory host. Pathogenesis, on the other hand, refers to a more intrinsic and constant characteristic of the parasite and is related to the ability of producing tissue lesions and mortality (Andrade 1985).

Many studies of biological characterization have demonstrated that $T$. cruzi strains originating from humans, reservoirs and vectors from distinct geographic regions show different behavior in laboratory animals (parasitaemia, tissue tropism and mortality rates) (Badinez 1945, Brand et al. 1949, Taliaferro \& Pizzi 1955, Deane et al. 1963, Andrade \& Magalhães 1997). This phenomenon is influenced by environmental and immunological factors, virulence, pathogenicity and possible selection of strains and clones after interacting with vectors and vertebrate hosts. The combination of several of these factors might explain the variability in the biological behavior of the parasite (Andrade et al. 1970, Bice \& Zeledón 1970, Magalhães et al. 1996).

Vianna (1911) showed that T. cruzi could be found in distinct tissues of the vertebrate host, although the parasite prefers certain cellular groups, according to Baldinez's theories in 1945. Since then, other authors demonstrated that the strain tropism is an important biological characteristic to be considered in laboratory animals (Andrade et al. 1970, Bice \& Zeledón 1970, Andrade 1974, Hanson \& Roberson 1974, Melo \& Brener 1978).

Some strains prefer muscle tissue (skeletal or cardiac) and are called miotropic, others are called reticulotropic strains because they prefer the phagocitic mononuclear 
cells and there is a third group which prefers other tissues (nervous, reproductive systems and others) (Dias 1934, Silva \& Nussenzweig 1953, Taliaferro \& Pizzi 1955, Andrade \& Andrade 1966, 1968, Watkins 1966, Andrade et al. 1970, Bice \& Zeledón 1970, Tay et al. 1973, Andrade 1974, Hanson \& Roberson 1974, Amaral et al. 1975, Melo \& Brener 1978, Lenzi et al. 1998).

The first attempt to group T. cruzi strains was based on morpho-biological criteria. Chagas (1909) observed the presence of circulating parasites of wide and slim forms. Brener and Chiari (1963) and Brener (1965) confirmed this finding demonstrating that these forms from distinct stocks, circulate in mice with different percentages. The slim forms are predominant in strains of extreme virulence and tropism to macrophages (Brener 1965, Andrade 1974). The wide forms are more common in miotropic strains and low virulence stocks. In addition, the slim forms are more susceptible to the host immune system (Brener \& Chiari 1963, Brener 1969). Brener (1977) suggested the classification of the stocks in two polar types based on morphology and on tissue tropism, describing an aggressive pole represented by the Y strains and a benign pole exemplified by the CL strain. It is important to emphasize that these are "elements for characterization" and are not, by themselves, sufficient to classify the $T$. cruzi strains.

The main problem regarding the biological characterization is the comparison of the strains that can be extremely difficult if the analysis is made stock by stock, due to their great variety. Taking into account this diversity and using biological parameters of the mouse-parasite interaction, such as parasitaemia, morphology, tissue tropism and histopathologic lesions, three groups of $T$. cruzi strains were proposed and named biodemes (Andrade 1974).

Biodeme I, which prototypes are the $\mathrm{Y}$ and the Peruvian strains, consists of a fast in vitro growth, high parasitaemia and mice mortality, which occurs between the 7 th and 12 th day post-infection. They present mostly slim trypomastigote forms and present tropism to macrophages in the initial phase of the infection. The São Felipe strain is the prototype of biodeme II that presents a slow multiplication with peaks of irregular parasitaemia between the 12th and 20th day post-infection, period of the highest mortality. In the initial phase of the infection, wide forms with a low percentage of slim forms predominate, as well as miotropism, damaging the heart muscle. Biodeme III, which prototype is the Colombian strain, multiplies slowly with peaks of late parasitaemia between the 20th and 30th day after the inoculum and low mortality rate - around the 50th day of infection. Wide forms are common, damaging specially the skeletal muscle. Furthermore, these biological types correspond to specific patterns of zymodemes (Andrade et al. 1983, Andrade \& Magalhães 1997).

\section{BIOCHEMICAL CHARACTERIZATION}

\section{Enzyme electrophoresis}

Enzyme electrophoresis uses raw and soluble extracts of an organism to evaluate the particular activity of a protein after electrophoresis and incubation with an appropriate substrate, revealing the product of the activity through a color reaction. Under controlled conditions, the differences in the isoenzymatic mobility imply in genetic differences (Miles 1985, Miles \& Cibulkis 1986). The results are analyzed through simple visual inspection or through mathematical procedures, based on rates of similarity or genetic distances (Ready \& Miles 1980, Miles 1985, Miles \& Cibulkis 1986).

Enzyme electrophoresis profiles (alanin aminotransferase, ALAT, and aspartate aminotransferase, ASAT) were introduced for the study of trypanosomes simultaneously by Kilgour and Godfrey (1973) and Bagster and Parr (1973), who managed to classify the African trypanosomes into species and sub-species.

For New World trypanosomes, Toyé (1974) was the first to use isoenzymes, observing differences between $T$. cruzi samples. Miles et al. (1977, 1978, 1980, 1981a, b) performed several studies on isoenzyme variability among $T$. cruzi stocks from Northeast, Brazil and subsequently, from different regions of this country, employing six enzymes: ALAT, ASAT, glucophosphate isomerase (GPI), glucose 6 phosphate dehydrogenase (G6PDH), malic enzyme (ME) e phosphoglucomutase (PGM), determining the existence of two different groups of strains named zymodemes 1 (Z1) and 2 (Z2).

Zymodeme 1 grouped marsupials and wild triatomine stocks and $\mathrm{Z} 2$ clustered domestic isolates derived from humans and domiciliated mammals. Additional studies showed a third zymodeme (Z3), also associated with sylvan environments. The diversity in Z2 is especially clear, although this heterogeneity is found in all the three zymodemes (Miles et al. 1977, 1980). This clustering was further confirmed by numerical taxonomy (Miles et al. 1978, Barrett et al. 1980, Ready \& Miles 1980).

Romanha (1982) and Carneiro et al. (1990) extended the multiloci enzyme electrophoresis (MLEE) analysis (eight enzymes - ALAT, ASAT, ME, PGM, G6PD, GPI, 6phosphate dehydrogenase - 6PGD, and malate dehydrogenase $-\mathrm{MDH}$ ), classifying the isolates into four different isoenzymatic groups (ZA, ZB, ZC e ZD), identifying a zymodeme harboring the wild strains $(\mathrm{ZB})$ and another one characteristic of the domestic transmission cycle of the parasite named ZA that corresponded to the aforementioned Z2 (Miles et al. 1980).

Tibayrenc and Ayala (1988) analyzed the enzymatic profile of 645 samples of $T$. cruzi using 15 loci. The samples varied in their geographic origin and had been isolated from a great number of triatomine bugs and vertebrate hosts. A high genetic variability was detected and 43 distinct zymodemes, alternatively named clonets, were identified. Based on the findings of the same clonet in distant geographic areas, the authors proposed a clonal population structure for T. cruzi.

The great heterogeneity of $T$. cruzi strains from distinct hosts and Latin America countries, through MLEE has been described (Tibayrenc \& Miles 1983, Miles et al. 1984, Bogliolo et al. 1985, Saravia et al. 1987, Carneiro et al. 1991, Montamat et al. 1992, Solari et al. 1992, Rodriguez et al. 1998, Araújo 2000, Pinho et al. 2000, Acosta et al. 2001) and the isoenzymatic profiles associated with other parameters, such as (i) clinical manifestations and geographic origin (Barrett et al. 1980, Apt et al. 1987, Brenière et al. 
1989, Montamat et al. 1996, Andrade \& Magalhães 1997, Rodriguez et al. 1998, Acosta et al. 2001), (ii) biological behavior (Andrade et al. 1983, Carneiro et al. 1990, 1991, Gomes et al. 1991, Steindel et al. 1995, Andrade \& Magalhães 1997, Araújo 2000), (iii) resistance to chemotherapy (Castro-Silva et al. 1989) and (iv) molecular markers (Solari et al. 1992, Steindel et al. 1993, Tibayrenc et al. 1993, Lauria-Pires et al. 1996, Fernandes et al. 1997, Brisse et al. 1998, 2000, Jaramillo et al. 1999). However, using MLEE no clear correlation has been found hitherto, with the clinical outcome of Chagas disease (Barrett et al. 1980, Apt et al. 1987, Brenière et al. 1989).

The stability of the T. cruzi isoenzymes has also been the target of investigation by several groups and noncoherent results have been described. Although the stability of the enzymatic profile, especially when cloned populations are studied, has been observed (Dvorak et al. 1980, Miles \& Cibulkis 1986, Gomes et al. 1991), variations have also been evidenced. Hence, it can be concluded that the isoenzymatic profile is not always stable (Romanha et al. 1979, Romanha 1982, Goldberg \& Pereira 1983, Tanuri \& Almeida 1984, Bogliolo \& Godfrey 1987, Carneiro et al. 1990).

Indeed, even when clones are used, the results can be discordant. Campos and Andrade (1996) studied clones and sub-clones of the 21SF strains showing stable profiles. On the other hand, Gomes et al. (1991) observed isoenzymatic homogeneity in some clones and heterogeneity in others. Goldberg and Pereira (1983) and Montamat et al. (1997) also observed isoenzymatic variations in cloned populations. Alves et al. (1993) emphasized the possibility of reversible changes in enzymatic profiles in T. cruzi strains kept in in vitro culture for a long period.

\section{Schizodeme analysis}

Molecular biology contributed with several technical approaches, which allowed the identification and classification of strains and clones, without the need of previous isolation and culturing of the parasites (Sturm et al. 1989, Ávila et al. 1991, Veas et al. 1991, Brenière et al. 1992, Vago et al. 1996, Andrade et al. 1999, Bosseno et al. 2000). However, the use of cultivated populations of parasites for DNA extraction is a constrain still faced in most of the molecular techniques, leading to an eventual selection of clones present in the original mix.

One of the techniques that does require previously cultivated parasites is the RFLP of the mitochondrial genome (kinetoplast DNA - kDNA) or schizodeme analysis. The RFLP of the kDNA was first introduced by Mattei et al. (1977) for the intrinsic classification of trypanosomes. Later, Morel et al. (1980) employed this method for genotyping $T$. cruzi strains and proposed the term schizodeme to refer to groups of parasites presenting the same RFLP of the kDNA. This technique is based on the electrophoretic separation of restriction fragments of the kDNA. Since then, it has been widely used (Deane et al. 1984a, Carreño et al. 1987, Gomes et al. 1991, Mimori et al. 1992, Solari et al. 1992, Alves et al. 1994, Gonzalez et al. 1995, Jaramillo et al. 1999).

Although considered as stable markers, the high heterogeneity of some strains can lead to the observation of different profiles when these strains are kept in laboratory animals or in in vitro culture, as these conditions could favor the selection of sub-populations of the parasite (Morel et al. 1980, 1986, Deane et al. 1984a, b, Gonçalves et al. 1984, Carneiro et al. 1990, Gomes et al. 1991, Alves et al. 1994).

\section{Mini-exon gene}

Concerning the nuclear DNA, there are several available molecular tools to characterize T. cruzi strains. The mini-exon gene (ME) is present in the nuclear genome of the Kinetoplastida in nearly 200 copies arranged in tandemly-repeated sequences, consisting of three distinct regions: exon, intron and intergenic region. The exon is a $39 \mathrm{bp}$ sequence, highly conserved among the components of the Order, being added post-transcriptionally to all nuclear messenger RNAs (mRNAs). The intron is moderately conserved among the species of the same genus or sub-genus and the intergenic region or non-transcribed spacer (NTS-ME) is particularly dissimilar among the species. In relation to T. cruzi in particular, a hypervariable spot of the NTS-ME can be amplified through the polymerase chain reaction (PCR), making it possible to classify different isolates into the two main taxonomic groups - T. cruzi I and T. cruzi II (Fernandes 1996, Souto et al. 1996, Fernandes et al. 1998). A more practical approach was recently propose to type $T$. cruzi strains using a multiplex PCR based on the NTS-ME, allowing to determine if a certain isolate is $T$. cruzi I, T. cruzi II, T. cruzi Z3 or $T$. rangeli (Fernandes et al. 2001).

\section{RAPD analysis}

Differences among the strains, their genetic diversity or variability, are easily revealed through the use of RAPD analysis, which proved to be an useful tool for trypanosomatids and other protozoan parasites (Dias Neto et al. 1993, Steindel et al. 1993, 1994, Tibayrenc et al. 1993, Gomes et al. 1995, Fernandes et al. 1997, Urdaneta et al. 2001). Since its introduction in 1990, this technique has been used in taxonomy and typing studies of microorganisms. It is a PCR-mediated technique that uses short primers of random sequences, which can amplify anonymous fragments of the target DNA, generating a multiple band patterns that can be strain-specific. The advantages of this technique are (i) the requirement of minimum amounts of target DNA, (ii) the acceptance of an unlimited number of primers, (iii) no requirement of previous knowledge of the sequences to be amplified (Welsh \& McClelland 1990, Willians et al. 1990, Steindel et al. 1993).

Regarding T. cruzi, the RAPD analysis is judged as a useful tool to obtain highly variable DNA markers, establishing genetic relations among the isolates (Dias Neto et al. 1993, Steindel et al. 1993, Tibayrenc et al. 1993, Souto et al. 1996, Fernandes et al. 1997, Bastrenta \& Brenière 1998, Brisse et al. 1998, 2000, Murta et al. 1998). Although complex band profiles can be evidenced individually, when these patterns are numerically analyzed, it is observed that $T$. cruzi, as a taxon, can be divided into two main groups (Tibayrenc 1995, Souto et al. 1996, Murta et al. 1998, Brisse et al. 2000). These two groups correspond to the major phylogenetic lineages of the parasite coinciding to T. cruzi I and II (Steindel et al. 1993, Tibayrenc et al. 
1993, Tibayrenc 1995, Souto et al. 1996, Fernandes et al. 1997, Brisse et al. 1998, 2000, Murta et al. 1998).

Using RAPD analysis, Carrasco et al. (1996) recognized that in Mexico, various populations belonging to $\mathrm{Z} 2$ and Z3 were circulating (Miles et al. 1980). Steindel et al. (1994) also confirmed the usefulness of RAPD analysis to differentiate $T$. cruzi and $T$. rangeli, a closely related New World trypanosome from several regions in Latin America.

\section{Internal region typing (RFLP-ITS rDNA)}

The ribosomal RNA (rRNA) genes (rDNA) are highly conserved and bear potential for phylogenetic analysis of trypanosomatids. In these protozoa, the rDNA is found as repeated sequences. The coding regions of the large and the small sub-units are separated by internal transcribed spacers (ITSs) flanking the 5.8S rRNA gene. The ITSs present sequences of great variability and as they are flanked by highly conserved segments, it is possible to design PCR primers that anneal in these latter regions (Cupolillo et al. 1995, Fernandes et al. 1999b). Cupolillo et al. (1995) standardized, using Leishmania as a model, the RFLP of the ITS rDNA, which was called Intergenic Region Typing (IRT). The amplified products correspond to the 5.8S rRNA gene plus the two flanking ITSs.

Variation in the sequences of the ITSs rDNA proved that the methodology was able to distinguish among Leishmania species (Cupolillo et al. 1995). This method was adapted and applied to the molecular characterization of T. cruzi strains (Fernandes et al. 1999b). Preliminary results showed that the RFLP-ITS rDNA is powerful to distinguish intra-specific variability in $T$. cruzi. It also allowed geographical clustering of the isolates belonging to T. cruzi II (Santos et al. pers. commun.) and confirmed the division of the taxon in two main groups.

Mendonça et al. (2002) recently analyzed the genetic diversity among Z3 stocks from the Brazilian Amazon using the RFLP-ITS rDNA approach, showing that such isolates could be divided into two sub-groups with distinct phylogenetic origins (Kawashita et al. 2001).

\section{Microsatellites}

The microsatellites are a class of a tandem-array repetitive DNA - in general around 1 to $6 \mathrm{bp}$ - that are dispersed in the eukaryotic genome. They can be classified according to the number of bases and thus are called mononucleotides, dinucleotides, trinucleotides, tetranucleotides, pentanucleotides and hexanucleotides (Weber 1990). Their number of copies of the repeated unit in a specific loci is extremely polymorphic and variation in the number of the repeats occurs also between the alleles.

The mutation rate of the microsatellites varies from $10^{-6}$ to $10^{-2}$ (Harr et al. 2000). This rate changes according to the number of the repeats in the array (Bachtrog et al. 2000, Xu et al. 2000).

Due to this polymorphism, microsatellites are considered election markers with great applications in the biomedical areas such as ecology, population genetics and phylogenetic reconstruction (Oliveira et al. 1998, Hawley \& Mori 1999, Bachtrog et al. 2000, Harr et al. 2000).

The main strategy employed in the analysis of microsatellites polymorphism is the PCR amplification of the loci, using a pair of specific primers that flank the segment containing the repeats, with further analysis of the size of the generated fragments (Hawley \& Mori 1999).

For T. cruzi, microsatellite analysis has been used for population genetic studies, phylogenetic reconstruction, and to define the clonality of a certain strain (Oliveira et al. 1998, Macedo et al. 2001). The methodology was originally developed by Oliveira et al. (1998) as a PCR-based technique that amplifies polymorphic loci of microsatellite, with cytosine-adenine (CA) repeats of the T. cruzi genome. A genomic library of the CL Brener strain, enriched 15 times to $\mathrm{CA}$ repeats was used and 17 microsatellites $(\mathrm{CA})_{\mathrm{n}}$ were selected where $\mathrm{n}>6$, out of which 8 were polymorphic.

The methodology was further incremented with the use of fluorescent primers to the PCR and analysis of the amplified fragments in automatic sequencer determining the size of the alleles (Oliveira et al. 1998). This approach clearly showed that $T$. cruzi strains are diploid and multiclonal (Oliveira et al. 1998, 1999).

The strains that display one or two peaks (one or two alleles, corresponding to diploid) are considered monoclonal. The appearance of more than two peaks in different loci, is indicative that more than one population is present (polyclonality). Oliveira et al. (1998, 1999) observed that the majority of the strains isolated from chronic chagasic patients are clonal while those from non-human hosts are multiclonal.

\section{Selection of $T$. cruzi populations: the role of vertebrate hosts and culture media}

T. cruzi isolates are composed of heterogeneous populations of the parasite and in vitro culturing and animal inoculation can select certain sub-populations of this mixture (Deane et al 1984a, b, c, Gonçalves et al. 1984, Lamel et al. 1985, Miles \& Cibulkis 1986, Morel et al. 1986, Aguiar 2002).

These "filters" might select those populations or clones that are more apt to the new environment. In the case of in vitro culturing, this selection can be achieved by changing the composition of the nutrients in the media. In vertebrate hosts the immune system may have an important role in this phenomenon (Lana et al. 1996, Oliveira et al. 1998).

\section{Animal infection}

The long-term maintenance of $T$. cruzi in laboratory animals leads to alterations in the biological features of the original strain. Regarding virulence for instance, the results are odd: reports of declination (Menezes, 1970a, b, Brener et al. 1974, Schlemper Jr. 1982, Araújo 2000) and intensification (Schlemper Jr. 1982, Carneiro et al. 1991) are described.

Veloso et al. (1996) reported a decline in the T. cruzi virulence after long-term maintenance in dogs. Lana and Chiari (1986) described similar results in mice and dogs, comparing the original Berenice strain and another stock isolated from the same patient 16 years afterwards.

There are clear evidences that support the selective role of the vertebrate host. Reports of changes in the isoenzymes profiles and in the RFLP of the kDNA after animal inoculation of an isolate are common (Deane et al. 1984a, 
b, c, Morel et al. 1986, Carneiro et al. 1990, Alves et al. 1993, Lauria-Pires et al. 1996, Lauria-Pires \& Teixeira 1996, Santana et al. 1998).

Morel et al. (1986), after maintaining T. cruzi in C3H mice for 18 months, observed that 5 out of 13 strains changed their isoenzymes and RFLP of the kDNA profile, confirming the selection of sub-populations of the parasite. After infecting mice with two different $T$. cruzi strains, Deane et al. (1984a, b, c) could re-isolate only one of them. They also confirmed the potential of the vertebrate host, in this case marsupial, in selecting sub-populations of the parasite when evidenced changes in the schizodeme analysis. More recently, after maintaining the Munantá strain in Balb/c mice, Santana et al. (1998) detected that from 9 of the studied enzymes, only one presented variation.

\section{In vitro culturing}

The long-term in vitro culturing of $T$. cruzi leads to the decrease in the virulence and infectivity of the strain to laboratory animals and this phenomenon has been explained by the selection of sub-populations that are better adapted to the in vitro culture media (Goble 1951, Pizzi \& Prager 1952b, Cavalheiro \& Collares 1965, Lambbrecht 1965, Bice \& Zeledón 1970, Chiari et al. 1973, Chiari 1974a, b, Postan et al. 1983, Deane et al. 1984a, Magalhães et al. 1985, Alves et al. 1993, Contreras et al. 1994).

Pizzi and Parger (1952a) inoculated sequentially, C3H mice with $T$. cruzi culture forms, every 10 days for 6 years, and observed the decline of infectivity corroborated by the absence of parasitaemia after the last infections. Cavalheiro and Collares (1965) demonstrated that the Y strain presents its biological characteristics changed after in vitro culturing. Menezes (1970a, b) and Chiari (1974a, b) observed a decline in the infectivity and virulence of a $T$. cruzi strain after long-term maintenance in culture media.

Some populations develop better than others do in in vitro systems, which results in modifications in the original genetic profile (Engel et al. 1982). Clones with a short duplication time might be selected by culture when compared to those that present long duplication time (Mangia 1995).

Contreras et al. (1994) maintained two T. cruzi strains for three years, with successive passages in cultures, detecting after this period that the metacyclogenesis had reduced, declining the virulence.

Lima et al. (1995) studied three clones of a stock isolated from a naturally infected marsupial, which were maintained during four years in LIT medium with monthly passages, and compared their growth kinetics and their duplication time. The studied parameters were considered non-stable and should not be used as biological markers, emphasizing that in vitro culturing does select $T$. cruzi sub-populations.

Rodriguez et al. (1998) examined seven T. cruzi strains isolated from different hosts in Colombia. One of them presented four distinct enzyme electrophoresis profiles out of 13, after being maintained during 35 in vitro passages.

Long-term in vitro culturing is determinant of phenotypic alterations - decrease in infectivity, virulence, and changes in enzyme electrophoresis profiles, and also of genotypic modifications, such as changes in the RFLP of the kDNA (Romanha et al. 1979, Romanha 1982, Goldberg \& Pereira 1983, Tanuri \& Almeida 1984, Morel et al. 1986, Bogliolo \& Godfrey 1987, Carneiro et al. 1990).

Alves et al. (1993) observed different isoenzymatic profiles in distinct clones of the T. cruzi $\mathrm{Y}$ strain that were submitted to long-term in vitro culturing. Later on, it was verified that these changes were followed by alterations in the RFLP of the kDNA. This phenomenon is called transkinetoplastid (Alves et al. 1994) and consists of fast changes in the kDNA minicircles population leading to different restriction profiles. Transkinetoplastid phenomenon was primarily observed in cloned cells of Leishmania amazonensis submitted to drug selection and is judged to be reversible. Probably components of the culture medium interfere with the transcription of certain genes, regulating essential activities of the kDNA minicircles, which transcripts are necessary to the proper mitosis (Lee et al. 1992).

\section{Human infection}

T. cruzi strains isolated form, different triatomine bugs, and vertebrate hosts have shown to be multiclonal populations (Dvorak 1984, Murfin et al. 1985, Morel et al. 1986, Oliveira et al. 1998, 1999). In a chronic chagasic patient, these populations may be selected during the long human-T. cruzi interaction and differential tissue tropism may interfere with the distribution of the sub-populations (Vago et al. 2000). This justify the common finding of homogeneous population being isolated from chronic chagasic patients (Gomes et al. 1998, Oliveira et al. 1999) when compared to stocks isolated during acute phases and from components of the sylvatic cycle (triatomine and mammals) (Morel et al. 1980, Fernandes et al. 1997, Oliveira et al. 1998, Solari et al. 1998).

Berenice, the first human case of Chagas disease, can exemplify a clear selective role being played by the human host. Two T. cruzi populations were isolated from this patient: the first one when she was 55 years old and the second when she was 71 years old. The zymodemes and the schizodemes profiles were different between them (Lana et al. 1996) and could be attributed to a re-infection with a new parasite strain or by the presence of an heterogeneous population in the patient since the very first isolate. The long-term interaction of Berenice and T. cruzi promoted the selection of a different $T$. cruzi population that was evidenced by the differences found in the second stock.

No correlation between the genetic variability of the parasite with the clinical outcome of the disease has been established. Probably the understanding if a patient will be assymptomatic or present the cardiac or digestive form of the disease will only be possible with the complete characterization of the parasite and of the complex human-parasite relationship that is evidenced in Chagas disease.

\section{"cruzi" complex}

The different biological and molecular approaches that have been used to study $T$. cruzi have shown the diversity of the distinct isolates of the parasite. The recent 
proposal of defining two groups to designate the major phylogenetic lineages of the protozoan, based on several molecular targets, have received support from the scientific community. However, there are still points that need to be addressed, such as the phylogenetic origin of $\mathrm{Z3}$ and the significance of genetic hybrids.

The concept of "cruzi" complex, proposed by Coura et al. (1966) should be revitalized not as a taxonomic nomenclature but as a clear form of depicting the diversity found in the taxon T. cruzi.

\section{REFERENCES}

Acosta N, Samudio M, López E, Vargas F, Yaksic N, Brenière SF, Aris AJ 2001. Isoenzyme profiles of Trypanosoma cruzi stocks from diferent areas of Paraguay. Mem Inst Oswaldo Cruz, 96: 527-533.

Aguiar RS 2002. Influência da Espécie de Triatomíneo na Seleção de Subpopulações em Infecções Mistas de Trypanosoma cruzi, MSc Thesis, Universidade Federal de Minas Gerais, Belo Horizonte, 128 pp.

Alves AMB, Almeida DF, Von Gruger WMA 1994. Changes in Trypanosoma cruzi kinetoplast DNA minicircles induced by enviromental conditions and subcloning. J Euk Microbiol 41: 415-419.

Alves AMB, Tanui A, Almeida DF, Von Gruger WMA 1993. Reversible changes in the izoenzyme electrophoretic mobility patterns and infectivity in clones of Trypanosoma cruzi. Exp Parasitol 77: 246-253.

Amaral CFS, Tafuri WL, Brener Z 1975. Freqüência do parasitismo encefálico em camundongos inoculados experimentalmente com diferentes cepas do T. cruzi. Rev Soc Bras Med Trop 9: 243-246.

Andrade LO, Machado CR, Chiari E, Pena SD, Macedo AM 1999. Differencial tissue distribution of diverse clones of Trypanosoma cruzi in infected mice. Mol Biochem Parasitol 100: 163-172.

Andrade SG 1974. Caracterização de cepas de Trypanosoma cruzi isoladas do Recôncavo Baiano: contribuição ao estudo da patologia geral da doença de Chagas em nosso meio. Rev Pat Trop 3: 65-121.

Andrade SG 1985. Morphological and behavioural characterization of Trypanosoma cruzi strains. Rev Soc Bras Med Trop 18 (Supl.): 39-46.

Andrade SG 1989. Patogenicidade de diferentes cepas do $T$. cruzi e a sua possível correlação com as formas clínicas. Rev Soc Bras Med Trop 22 (Supl. II): 15-17.

Andrade SG 1990. Influence of Trypanosoma cruzi strain on the pathogenesis of chronic myocardiopathy in mice. Mem Inst Oswaldo Cruz 85: 17-27.

Andrade SG 1999. Trypanosoma cruzi: clonal structure of parasite strain and the importance of principal clones. Mem Inst Oswaldo Cruz 94 (Suppl. I): 185-187.

Andrade SG 2000. Patologia experimental da doença de Chagas. In Z Brener, Z Andrade, M Barral-Netto (eds), Trypanosoma cruzi e Doença de Chagas, Guanabara Koogan, Rio de Janeiro, p. 177-200.

Andrade SG, Andrade ZA 1966. Estudo histopatológico comparativo das lesões produzidas por duas cepas do Trypanosoma cruzi. Hospital 70: 1268-1278.

Andrade SG, Andrade ZA 1968. Patologia da doença de Chagas experimental de longa duração. Rev Inst Med Trop São Paulo 10: 180-187.

Andrade SG, Campos RFM 1998. Estrutura clonal das cepas do Trypanosoma cruzi: importância de clones principais. Rev Soc Bras Med Trop 31 (Supl. II): 21-22.

Andrade SG, Magalhães JB 1997. Biodemes and zymodemes of Trypanosoma cruzi strains: correlations with clinical data and experimental pathology. Rev Soc Bras Med Trop 30: 27-35.

Andrade SG, Carvalho ML, Figueira R 1970. Caracterização morfo-biológica e histopatológica de diferentes cepas do Trypanosoma cruzi. Gaz Med Bahia 70: 32-42.

Andrade V, Andrade SG, Barral Netto M, Pontes A, Castro R 1985. Avaliação do comportamento de diferentes cepas do Trypanosoma cruzi na infecção de seis linhagens isogênicas de camundongos. Rev Soc Bras Med Trop 18: 143-154.

Andrade V, Brodskyn C, Andrade SG 1983. Correlation between isoenzyme patterns and biological behaviour of different strains of Trypanosoma cruzi. Trans R Soc Trop Med Hyg 77: 796-799.

Anonymous 1999. Recommendations from a satellite meeting. Mem Inst Oswaldo Cruz 94 (Suppl. II): 429-432.

Apt W, Aguilera X, Arribada A, Gomez L, Miles MA, Widmer G 1987. Epidemiology of Chagas disease in northern Chile: isozyme profiles of Trypanosoma cruzi from domestic and sylvatic transmission cycles and their association with cardiopathy. Am J Trop Med Hyg 37: 302-307.

Araújo IB 2000. Estudo Morfobiológico e Izoenzimático de Amostras de Trypanosoma cruzi, Trypanosoma rangeli Isoladas de Casos Humanos, de Vetores e de Mamíferos Silvestres da Região do Médio e Alto Rio Negro-Amazonas, MSc Thesis,Instituto Oswaldo Cruz, Rio de Janeiro, 76 pp.

Araújo SM, Chiari E 1988. Caracterização biológica de clones das cepas Y, CL e MR de Trypanosoma cruzi em camundongos $\mathrm{C}_{3} \mathrm{H}$ isogênicos. Mem Inst Oswaldo Cruz 83: $175-181$.

Araújo-Jorge T 2000. Modelos animais para o estudo in vivo da doença de Chagas e de seus aspectos histopatológicos. O camundongo. In TC Araújo-Jorge, SL Castro (orgs) Doença de Chagas: Manual para Experimentação Animal, Fiocruz, Rio de Janeiro, p.133-139.

Ávila HA, Sigman DS, Cohen LM, Millikan RC, Simpson L 1991. Polymerase chain reaction amplification of Trypanosoma cruzi kinetoplast minicircle DNA isolated from whole blood lysates: diagnosis of chronic Chagas disease. Mol Biochem Parasitol 48: 211-222.

Bachtrog D, Agis M, Imhof M, Schlotterer C 2000. Microsatellite variability differs between dinucleotide repeat motifs-Evidence from Drosophila melanoganster. Mol Biol Evol 17: 1277-1285.

Badinez SO 1945. Contribuición a la anatomia patológica de la enfermedad de Chagas experimental. Biológica 3: 3-52.

Barrett TB, Hoff RH, Mott KE, Miles MA, Godfrey DG, Teixeira R, Almeida de Souza JA, Scherlock IA 1980. Epidemiological aspects of three Trypanosoma cruzi zymodemes in Bahia State, Brazil. Trans $R$ Soc Trop Med Hyg 74: 84-90.

Baruffa G 1977. Prevalência sorológica da doença de Chagas e correlação sorológica-eletrocardiográfica em populações não selecionadas do município de São Lourenço do Sul-RS. Rev Soc Bras Med Trop 11: 123-132.

Bice DE, Zeledón R 1970. Comparison of infectivity of strains of Trypanosoma cruzi (Chagas, 1909). J Parasitol 56: 663670.

Bogliolo AR, Godfrey DG 1987. Isoenzyme changes during the cycle of Trypanosoma cruzi. Trans $R$ Soc Trop Med Hyg 81: 222-229.

Bogliolo AR, Lanham SM, Corredor A 1985. Further enzyme polymorphism in Trypanosoma cruzi from Colombia. Braz J Med Biol Res 18: 427-433.

Borges-Pereira J, Coura JR 1987. Morbidade da doença de Chagas em populações urbanas do sertão da Paraiba. Rev Soc Bras Med Trop 20: 101-107. 
Bosseno MF, Yaksic N, Vargas F, Brenière SF 2000. Selection of Trypanosoma cruzi clonal genotypes (clonet 20 and 39) isolated from Bolivian triatomines following subculture in liquid medium. Mem Inst Oswaldo Cruz 95: 601-607.

Brand T, Tobie EJ, Kissling ER, Adams G 1949. Physiological and pathological observations on four strains of Trypanosoma cruzi. J Infect Dis 82: 5-16.

Brener Z 1962. Therapeutic activity and criterion of cure on mice experimentally infected with Trypanosoma cruzi. Rev Inst Med Trop São Paulo 4: 398-396.

Brener Z 1965. Comparative studies of different strains of Trypanosoma cruzi. Ann Trop Med Parasitol 59: 19-26.

Brener Z 1969. The behavior of slender and stout forms of Trypanosoma cruzi in the blood stream of normal and immune mice. Ann Trop Med Parasitol 63: 215-220.

Brener Z 1977. Intraspecific variation in Trypanosoma cruzi: two types of parasite populations resenting distintic characteristics. PAHO Scientific Public 347: 11-21.

Brener Z, Chiari E 1963. Variações morfológicas observadas em diferentes amostras de Trypanosoma cruzi. Rev Inst Med Trop São Paulo 5: 220-224.

Brener Z, Chiari E, Alvarenga J 1974. Observations on Trypanosoma cruzi strains maintained over an 8-year period in experimental inoculated mice. Rev Inst Med Trop São Paulo 16: 39-46.

Brenière SF, Bosseno MF, Revollo S, Rivera MT, Carlier Y, Tibayrenc M 1992. Direct identification of Trypanosoma cruzi natural clones in vectors and mammalian hosts by polymerase chain reaction amplification. Am J Trop Med Hyg 46: 335-341.

Brenière SF, Carrasco R, Revollo S, Aparicio G, Desjeux P, Tibayrenc M 1989. Chagas' disease in Bolivia: clinical and epidemiological features and zymodeme variability of Trypanosoma cruzi strains isolated from patients. Am J Trop Med Hyg 41: 521-529.

Brisse S, Barnabé C, Bañuls AL, Sidibé I, Noel S, Tibayrenc M 1998. A phylogenetic analisis of the Trypanosoma cruzi genoma project CL Brener reference strain by multilocus enzyme eletrophoresis and multiprimer random amplified polymorphic DNA fingerprinting. Mol Biochem Parasitol 92: 253-263.

Brisse S, Barnabé C, Tibayrenc M 2000. Identification of six Trypanosoma cruzi phylogenetic lineages by random amplified polymorphic DNA and multilocus enzyme eletrophoresis. Inter J Parasitol 30: 35-44.

Campos RMF, Andrade SG 1996. Characterization of subpopulations (clones and subclones) of the $21 \mathrm{SF}$ strain of Trypanosoma cruzi after long lasting maintenance in the laboratory. Mem Inst Oswaldo Cruz 91: 795-800.

Carneiro M, Chiari E, Gonçalves AM, da Silva AA, Pereira CM, Morel CM, Romanha AJ 1990. Changes in the isoenzyme and kinetoplast DNA patters of Trypanosoma cruzi strains induced by maintenance in mice. Acta Trop 47: 3545.

Carneiro M, Romanha AJ, Chiari E 1991. Biological characterization of Trypanosoma cruzi strains from different zymodemes and schizodemes. Mem Inst Oswaldo Cruz 86: 387-393.

Carrasco H, Frame IA, Valente SA, Miles MA 1996. Genetic exchange as a possible source of genomic diversity in sylvatic populations of Trypanosoma cruzi. Am J Trop Med Hyg 54: 418-424.

Carreño H, Rojas C, Aguilera X, Apt W, Miles M, Solari A 1987. Schizodeme analyses of Trypanosoma cruzi zymodemes from Chile. Exp Parasitol 64: 252-260.

Castro Silva R, Santiago CMG, Pontes AL, Andrade SG 1989.
Padrão isoenzimático da cepa Y do Trypanosoma cruzi após quimioterapia específica. Mem Inst Oswaldo Cruz 84: 8186.

Cavalheiro JR, Collares EF 1965. Estudos sobre o comportamento, em camundongos, de uma amostra altamente virulenta de T. cruzi (amostra Y), após passagens em triatomíneos, ratos e culturas. Rev Brasl Biol 25: 169-175.

Chagas C 1909. Nova tripanosomíase humana. Mem Inst Oswaldo Cruz 1: 159-218.

Chiari E 1974a. Infectivity of Trypanosoma cruzi metacyclic trypomastigotes from culture kept in laboratory for different periods of time. Rev Inst Med Trop São Paulo 16: 6167.

Chiari E 1974b. Growth and differentiation of Trypanosoma cruzi culture form kept in laboratory for different periods of time. Rev Inst Med Trop São Paulo 16: 81-87.

Chiari E, Tafuri WL, Alvarenga NJ, Soares SJ 1973. Observações sobre o comportamento no hospedeiro vertebrado de diferentes culturas do Trypanosoma cruzi. Rev Inst Med Trop São Paulo 15: 225-260.

Contreras VT, Araque W, Delgado VS 1994. Trypanosoma cruzi: metacyclogenesis in vitro-. Changes in the properties of metaciclic trypomastigotes maintained in the laboratory by different methods. Mem Inst Oswaldo Cruz 89: 253-259.

Contreras VT, de Lima AR, Zorrilla G 1998. Trypanosoma cruzi: maintennance in culture modify gene and antigenic expression of metacyclic trypomastigotes. Mem Inst Oswaldo Cruz 93: 573-760.

Coura JR 1966. Contribuição ao estudo da doença de Chagas no Estado da Guanabara. Rev Bras Malariol D Trop 18: 9-98.

Coura JR, Ferreira LF, Rubens J, Pereira NC, Silva JR 1966. Tripanosoma do "complexo cruzi" em reservatório silvestre no Estado da Guanabara. Estudo de sua patogenicidade. Rev Inst Med Trop São Paulo 8 125-133.

Cupolillo E, Grimaldi Jr G, Momen H, Beverley S 1995. Intergenic region typing (IRT) a rapid molecular approach to the characterization and evolution of Leishmania. Mol Biochem Parasitol 73: 145-155.

Deane MP, Brito T, Deane LM 1963. Pathogenity to mice of same strains of Trypanosoma cruzi isolated from wild animals. Rev Inst Med Trop São Paulo 5: 225-235.

Deane MP, Jansen AM, Mangia RHR, Gonçalves AM, Morel CM 1984a. Are our laboratory "strain" representative sample of Trypanosoma cruzi population that circulate in nature? Mem Inst Oswaldo Cruz 79 (Suppl.): 19-24.

Deane MP, Mangia RHR, Pereira NM, Gonçalves AM, Momen H, Morel CM 1984b. Trypanosoma cruzi: strain selection by different schedules of mouse passage of an initial mixed infection. Mem Inst Oswaldo Cruz 79: 495-497.

Deane MP, Sousa MA, Mangia RHR, Pereira NM, Momen H, Gonçalves AM, Morel CM 1984c. Trypanosoma cruzi: inoculation schedules and re-isolation methods select individual strains from doubly infected mice, as demonstrated by schizodeme and zimodeme analysis. J Protozool 31: 276-280.

Dias E 1934. Estudos sobre o Schizotripanum cruzi. Mem Inst Oswaldo Cruz 28: 1-110.

Dias Neto E, Steindel M, Passos LK, Souza CP, Rollinson D, Katz N, Romanha AJ, Pena SD, Simpson AJ 1993. The use of RAPDs for the study of the genetic diversity od Schistosoma mansoni and Trypanosoma cruzi. EXS 67: 339-345.

Dvorak JA 1984. The natural heterogeneity Trypanosoma cruzi: biological and medical implications. J Cell Biochem 24: 357371.

Dvorak JA, Hartman DL, Miles MA 1980. Trypanosoma cruzi: correlation of growth kinetics to zimodeme type in clones 
derived from various sources. J Parasitol 27: 472-474.

Engel JC, Dvorak JA, Segura EL, Crane MST 1982. Trypanosoma cruzi: biological characterization of 19 clones derived from two chronic chagasic patients. I. Growth kinetics in liquid medium. J Protozool 29: 555-560.

Fernandes CD, Murta SMF, Cerávolo IP, Krug LP, Vidigal PG, Steindel M, Nardi N, Romanha AJ 1997. Characterization of Trypanosoma cruzi isolated from chronic chagasic patients, triatomines and opossums naturally infected from the state of Rio Grande do Sul, Brazil. Mem Inst Oswaldo Cruz 92: 343-351.

Fernandes JF 1970. Estudo atual da vacinação contra a Doença de Chagas. J Bras Med 18: 105-108.

Fernandes O 1996. Análise da Estrutura Primária do Gene de Mini-exon em Diferentes Tripanosomatídeos e sua Utilização como Marcador Molecular, PhD Thesis, Instituto Oswlado Cruz, Rio de Janeiro, 268 pp.

Fernandes O, Mangia RH, Lisboa CV, Pinho AP, Morel CM, Zingales B, Campbell DA Jansen AM 1999a. The complexity of the sylvatic cycle of Trypanosoma cruzi in Rio de Janeiro state (Brazil) revealed by the non-transcribed spacer of the mini-exon gene. Parasitology 118: 161-166.

Fernandes O, Santos SS, Cupolillo E, Mendonça B, Derre R, Junqueira ACV, Santos LC, Sturm NR, Naiff RD, Barrett TB, Campbell DA, Coura JR 2001. A mini-exon multiplex polymerase chain reaction to distinguish the major groups of Trypanosoma cruzi and T. rangeli in the Brazilian Amazon. Trans R Soc Trop Med Hyg 95: 97-99.

Fernandes O, Santos SS, Junqueira ACV, Jansen AM, Cupolillo E, Campbell DA, Zingales B, Coura JR 1999b. Populational heteregeneity of Brazilian Trypanosoma cruzi isolates revealed by the mini-exon and ribosomal spacers. Mem Inst Oswaldo Cruz 94 (Suppl. I): 195-197.

Fernandes O, Souto RP, Castro JA, Pereira JB, Fernandes NC, Junqueira AC, Naiff RD, Barrett TB, Degrave W, Zingales B, Campbell DA, Coura JR 1998. Brazilian isolates of Trypanosoma cruzi from human and triatomines classificated into two lineages using mini-exon and ribosomal RNA sequence. Am J Trop Med Hyg 58: 807-811.

Goble F 1951. Studies on experimental Chagas disease in mice in relation to chemotherapeutic testing. J Parasitol 37: 408414.

Goldberg SS, Pereira AA 1983. Enzyme variation among clones of Trypanosoma cruzi. J Protozool 69: 91-96.

Gomes ML, Macedo AM, Pena SDJ, Chiari E 1998. Genetic relationship between Trypanosoma cruzi strains isolated from chronic chagasic patients in southern Brazil as revealed by RAPD and SSR-PCR analysis. Acta Trop 69: 99109.

Gomes ML, Romanha AL, Gonçalves AM, Chiari E 1991. Stability of isoenzyme and kinetoplast DNA (k-DNA) patterns in sussessively cloned Trypanosoma cruzi populations. Mem Inst Oswaldo Cruz 86: 379-385.

Gonçalves A, Nehme NS, Morel C 1984. Tripanosomatid characterization by schisodeme analysis. In C Morel, Genes and Antigens of Parasites. A Laboratory Manual, 2nd ed., Fundação Oswaldo Cruz, Rio de Janeiro, 95-109.

Gonzalez J, Muñoz S, Ortiz S, Anacona D, Salgado S, Galleguillos M, Neira I, Sagua H, Solari A 1995. Biochemical, inmunological and biological characterization of Trypanosoma cruzi populations of the Andean North of Chile. Exp Parasitol 81: 125-135.

Hanson WL, Roberson EL 1974. Density of parasites in various organs and the relation to numbers of trypomastigotes in the blood during acute infections of Trypanosoma cruzi in mice. J Protozool 21: 512-517.
Harr B, Sangerl B, Schlotterer C 2000. Removal of microsatellite interruptions by DNA replication slippage: phylogenetic evidence from Drosophila. Mol Biol Evol 17: 1001-1009.

Hawley RS, Mori CA 1999. The Human Genome: a User's Guide, Harcourt Academic Press, New York, 365 pp.

Henriksson J, Petterson U, Solari A 1993. Trypanosoma cruzi: correlation betweem karyiotype variability and isoenzyme classification. Exp Parasitol 77: 334-348.

Hoare CA 1964. Morphological and taxonomic studies mammalian trypanosomes X. Revision of the systematics. $J$ Protozool 11: 200.

Jaramillo N, Moreo J, Triana O, Arcos-Burgos M, Muñoz S, Solari A 1999. Genetic structure and phylogenetic relationships of colombian Trypanosoma cruzi populations as determined by schizodeme and isoenzyme markers. Am J Trop Med Hyg 61: 989-993.

Kawashita SY, Sanson GFO, Fernandes O, Zingales B, Briones MRS 2001. Maximum-likelihood divergence data estimates based on rRNA gene sequences suggest two scenarios of Trypanosoma cruzi intraspecific evolution. Mol Biol Evol 18: 2250-2259.

Kilgour V, Godfrey DG 1973. Species characteristics isoenzymes of two aminotransferases in trypanosomas. Nature 244: 69-70.

Lambbrecht FK 1965. Biological variations in trypanosomes and their relation to the epidemiology of Chagas disease. Rev Inst Med Trop São Paulo 7: 346-352.

Lamel EL, Muller LA, Isola ELD, González Cappa SM 1985. Effect of vector on infectivity of Trypanosoma cruzi. Acta Trop 42: 149-155.

Lana M, Chiari CA 1986. Caracterização biológica comparativa das cepas Berenice e Berenice-78 de Trypanosoma cruzi isoladas da mesma paciente em diferentes períodos. $\mathrm{Mem}$ Inst Oswaldo Cruz 81: 247-253.

Lana M, Chiari CA, Chiari E, Morel CM, Gonçalves AM, Romanha AJ 1996. Characterization of two isolates of Trypanosoma cruzi obtained from the patient Berenice, the first human case of Chagas disease described by Carlos Chagas in 1909. Parasitol Res 82: 257-260.

Lauria-Pires L, Teixeira RL 1996. Virulence and pathogenicity associated with diversity of Trypanosoma cruzi stocks and clones derived from Chagas' disease patients. Am J Trop Med Hyg 55: 304-310.

Lauria-Pires L, Bogliolo AR, Teixeira RL 1996. Diversity of Trypanosoma cruzi stocks and clones derived from Chagas disease patients: II. Isozyme and RFLP characterizations. Exp Parasitol 82: 182-190.

Lauria-Pires L, Santana JM, Tavares FS, Teixeira RL 1997. Diversity of Trypanosoma cruzi stocks and clones derived from Chagas disease patients: I. Behavioral characterization in vitro. Rev Soc Brasil Med Trop 30: 187-192.

Lee SY, Lee ST, Chang KP 1992. Transkinetoplastidy: a novel phenomenon involving bulk alterations of mitochondrionkinetoplast DNA of a trypanosomatid protozoan. $J$ Protozool 39: 190-196.

Lenzi H, Castelo-Branco MTL, Pelajo-Machado M, Oliveira DN, Lima MT, Gattass CR 1998. Trypanosoma cruzi: compromise of reproductive system in acute murine infection. Acta Trop 71: 117-129.

Lima VS, Mangia RH, Jansen AM 1995. Trypanosoma cruzi clones: growth kinetics and doubling time after a long term "in vitro" maintenance. Mem Inst Oswaldo Cruz,90 ( Suppl. I): 93 .

Macedo AM, Pena SDJ 1998. Genetic variability of Trypanosoma cruzi: implications for the pathogenesis of Chagas' disease. Parasitol Today 14: 119-123. 
Macedo AM, Martins SM, Chiari E, Pena SDJ 1992. DNA fingerprinting of Trypanosoma cruzi: a new tool for characterization of strains and clones. Mol Biochem Parasitol 55: 147-154.

Macedo AM, Pimenta J, Aguiar RS, Melo AIR, Chiari E, Zingales B, Pena SDJ, Oliveira RP 2001. Usefulness of microsatelites typing in population genetic studies of Trypanosoma cruzi. Mem Inst Oswaldo Cruz 96: 407-413.

Magalhães JB, Andrade SG, Sherlock I 1996. Trypanosoma cruzi strains: behavior after passage into authoctonus or foreign species of triatomines (biological and biochemical patterns). Rev Inst Med Trop São Paulo 38: 23-28.

Mangia RHR 1995. Trypanosoma cruzi: Caracterização Biológica e Bioquímica de Clones de um Mesmo Isolado Obtido de Didelphis marsupialis Naturalmente Infectado, MSc Thesis, Instituto Oswaldo Cruz,. Rio de Janeiro, 50 pp.

Mattei M, Goldenberg S, Morel C, Azevedo HP, Roitman I 1977. Biochemical strain characterization of Trypanosoma cruzi by restriction endonuclease cleavage of kinetoplastDNA. FEBS Lett 74: 264-268.

Mello RC, Brener Z 1978. Tissue tropism of different Trypanosoma cruzi strains. J Parasitol 64: 314-332.

Mendonça MB, Nehme NS, Santos SS, Cupolillo E, Vargas N, Junqueira A, Naiff RD, Barrett TB, Coura JR, Zingales B, Fernandes O 2002. Two main clusters within Trypanosoma cruzi zymodeme 3 are defined by distintict regions of the ribosomal RNA cistron. Parasitology 124: 177-184.

Menezes H 1970a. I - The avirulence of the cultivated Y strain of Trypanosoma cruzi. Rev Inst Med Trop São Paulo 12: 64-68.

Menezes H 1970b. II - The avirulence of the cultivated Y strain of Trypanosoma cruzi. Rev Inst Med Trop São Paulo 12: 129-135.

Miles MA 1983. The epidemiology of South American typanosomiasis - Biochemical and inmunological approaches and their relevance to control. Trans $R$ Soc Trop Med Hyg 77: 5-23.

Miles MA 1985. Isozyme characterization. Rev Soc Bras Med Trop 18 (Suppl.): 53-59.

Miles MA, Cibulkis R 1986. Zymodeme characterization of Trypanosoma cruzi. Parasitol Today 2: 94-97.

Miles MA, Apt W, Widmer G, Povoa MM, Schofield CJ 1984. Isozyme heterogeneity and numerical taxonomy of Trypanosoma cruzi stocks from Chile. Trans $R$ Soc Trop Med Hyg 78: 526-535.

Miles MA, Cedillos RA, Povoa M, Souza AA, Prata A, Macedo V 1981a. Do radically dissimilar Trypanosoma cruzi (Zymodemes) cuase Venezuelan and Brazilian form of Chagas' disease? Lancet $i$ : 1338-1340.

Miles MA, Lanhan SM, de Souza AA, Povoa DG 1980. Further enzymic characters of Trypanosoma cruzi and their evaluation for strain identification. Trans $R$ Soc Trop Med Hyg 74: 221-242.

Miles MA, Povoa M, Souza AA, Lainson R, Shaw JJ, Ketteridge DS 1981b. Chagas' disease in the Amazon Basin: II. The distribution of Trypanosoma cruzi zymodemes 1 and 3 in Pará State, north Brazil. Trans $R$ Soc Trop Med Hyg 75: 667-674.

Miles MA, Souza AA, Povoa M, Shaw JJ, Lainson R, Toye PJ 1978. Isozymic heterogenity of Trypanosoma cruzi in the first autochthonous patients with Chagas disease in Amazonian Brazil. Nature 272: 819-821.

Miles MA, Toye PJ, Oswald SC, Godfrey DG 1977. The identification by isoenzyme patterns of two distinct strain-groups of Trypanosoma cruzi circulating independently in a rural area of Brazil. Trans R Soc Trop Med Hyg 71: 217-225.

Mimori T, Maldonado M, Samudio M, Arias AR, Moreno R, Sakamoto M 1992. Characterization of Trypanosoma cruzi isolates from Paraguay, using restriction enzyme analisys of kinetoplast DNA. Ann Trop Med Parasitol 86: 231-237.

Montamat EE, de Luca D'Ouro GM, Perret B, Rivas C 1992. Characterization of Trypanosoma cruzi from Argentina by electroforic zymograms. Acta Trop 50: 125-133.

Montamat EE, de Luca D'Ouro L, Gallerano RH, Sosa R, Blanco A 1996. Characterization of Trypanosoma cruzi populations by zimodemes: correlation with clinical picture. Am J Trop Med Hyg 55: 625-628.

Morel CM, Chiari E, Camargo EP, Mattei DM, Romanha AJ, Simpson L 1980. Strains and clones of Trypanosoma cruzi can be characterized by pattern of restriction endonuclease products of kinetoplast DNA minicircles. Proc Natl Acad Sci USA 77: 6810-6814.

Morel CM, Deane MP, Gonçalves AM 1986. The complexity of Trypanosoma cruzi populations revealed by schizodeme analysis. Parasitol Today 2: 97-100.

Murfin DJ, Choromanski L, Kuhn RE 1985. Production and characterization of clones of the Brazil strain of Trypanosoma cruzi. J Parasitol 71: 525-529

Murta SMF, Gazzinelli RT, Brener Z, Romanha AJ 1998. Molecular characteriation of susceptible and naturally resisntant strains of Trypanosoma cruzi to benznidazole and nifurtimox. Mol Biochem Parasitol 93: 203-214.

Oliveira EC, Stefani MMA, Campos DE, Andrade ALSS, Silva SA, Rasi A, Luquetti AO 1997. Trypanosoma cruzi stocks isolated from acute Chagas disease patient lead to lethal murine infection. Trans R Soc Trop Med Hyg 91: 25-27.

Oliveira EC, Stefani MMA, Luquetti AO, Vêncio EF, Moreira MAR, Souza C, Rezende JM 1993. Trypanosoma cruzi and experimental Chagas' disease: characterization of a stock isolated from a patient with associated digestive and cardiac form. Rev Soc Bras Med Trop 26: 25-33.

Oliveira RP, Broude NE, Macedo AM, Cantor CR, Smith CL, Pena SDJ 1998. Probing the genetic population structure of Trypanosoma cruzi with polymorphic microsatellites. Proc Natl Acad Sci USA 95: 3776-3780.

Oliveira RP, Melo AIR, Macedo AM, Chiari E, Pena SDJ 1999. The population structure of Trypanosoma cruzi: expanded analysis of 54 strains using eight polymorphic CA-repeat microsatellites. Mem Inst Oswaldo Cruz 94 (Suppl. I): 6570.

Penin P, Gamallo C, Diego JA 1996. Biological Comparison betweem three clones of Trypanosoma cruzi and strain of origin (Bolivia) with reference to clonal evolution studies. Mem Inst Oswaldo Cruz 91: 185-191.

Petana WB, Coura JR 1974. Experimental studies on Trypanosoma (Schizotrypanum) cruzi strains isolated from man, animals and from triatomine bugs in Brazil. Rev Soc Bras Med Trop 8: 315-323.

Pinho AP, Cupolillo E, Mangia RE, Fernandes O, Jansen AM 2000. Trypanosoma cruzi in the sylvatic environment: distint transmission cycles involving two sympatric marsupials. Trans R Soc Trop Med Hyg 94: 1-6.

Pizzi T, Prager RS 1952a. Estabilización de la virulencia de una cepa de Trypanosoma cruzi por la pasaje seriada en ratones de constitución genética uniforme: analisis cuantitativo del curso de la infección. Biológica 16/17: 3-12.

Pizzi T, Prager RS 1952b. Inmunidad a la sobreinfección inducida mediante cultivos de Trypanosoma cruzi de virulencia atenuada. Bol Infor Parasit Chil 7: 20-21.

Pompeu FR 1990. Estudo Longuitudinal da Doença de Chagas em Trabalhadores Rurais do Municipio de Luz, Minas 
Gerais (1976-1985), MSc Thesis, Universidade Federal de Minas Gerais, Belo Horizonte, 129 pp.

Postan M, Dvorak JA, McDaniel JP 1983. Studies of Trypanosoma cruzi clones in inbred mice. I. A comparison of the course of infection of $\mathrm{C} 3 \mathrm{H} / \mathrm{HEN}^{-}$mice. Am J Trop Med Hyg 32: 497-506.

Ready PD, Miles MA 1980. Delimitation of Trypanosoma cruzi zymodemes by numerical taxonomy. Trans $R$ Soc Trop Med Hyg 74: 238-242.

Rodriguez P, Montilla M, Nicholls S, Zarante I, Puerta C 1998. Isoenzymatic characterization of Colombian strains of Trypanosoma cruzi. Mem Inst Oswaldo Cruz 93: 739-740.

Romanha AJ 1982. Heterogeneidade Isoenzimatica em Trypanosoma cruzi, $\mathrm{PhD}$ Thesis, Universidade Federal de Minas Gerais, Belo Horizonte, 110 pp.

Romanha AJ, Silva-Pereira AA, Chiari E, Kilgour V 1979. Isoenzyme patterns of cultured Trypanosoma cruzi changes after prolonged subculture. Com Bichem Physiol 62B: 139142.

Santana LA, Montilla M, Nicholls S, Puerta CJ 1998. Variación antigénica de la cepa Munantá de Trypanosoma cruzi después de pase por ratón. Biomedica 18: 134-140.

Saravia NG, Holguin AF, Cibulkis RE, D’ Alessandro A 1987. Divergent isoenzyme profiles of sylvatic and domiciliary Trypanosoma cruzi in the easthern plains, piedmont, and highlands of Colombia. Am J Trop Med Hyg 36: 59-69.

Schlemper Jr BR 1982. Caracterização de Cepas do Trypanosoma cruzi Isoladas de Pacientes com Diferentes Formas Clínicas da Doença de Chagas, PhD Thesis, Universidade Federal de Rio de Janeiro, Rio de Janeiro, 131 pp.

Silva LHP, Nussenzweig V 1953. Sobre uma cepa de Trypanosoma cruzi altamente virulenta para o camundongo branco. Fol Clin Biol 20: 191-207.

Solari A, Muñoz S, Venegas J, Wallace A, Aguilera X, Apt W, Brenière SF, Tibayrenc M 1992. Characterization of Chilean, Bolivian, and Argentinian Trypanosoma cruzi populations by restriction endonuclease and isoenzyme analisis. Exp Parasitol 75: 187-195.

Solari A, Wallace A, Ortiz S, Venegas J, Sanchez G 1998. Biological characterization of Trypanosoma cruzi stocks from Chilean insect vectors. Exp Parasitol 89: 312-322.

Souto RP, Fernandes O, Macedo AM, Campbell, Zingales B 1996. DNA markers define two major phylogenetic lineages of Trypanosoma cruzi. Mol Biochem Parasitol 83: 141-152.

Steindel M, Dias Neto E, Menezes C, Romanha A, Simpson AJG 1993. Random amplified polymorphic DNA analysis of Trypanosoma cruzi strains. Mol Biochem Parasitol 60: 71-80.

Steindel M, Dias Neto E, Pinto CJ, Grisard EC, Menezes CLP, Murta SMF, Simpson AJG, Romanha A. 1994. Random amplified polymorphic DNA (RAPD) and isoenzyme analisis of Trypanosoma rangeli strains. J Euk Microbiol 41: 261-267.

Sturm NR, Degrave W, Morel C, Simpson L 1989. Sensitive detection and schizodeme classification of Trypanosoma cruzi cells by amplification of kinetoplast minicircle DNA sequences: use in diagnosis of Chagas' disease. Mol Biochem Parasitol 15: 205-214.

Taliaferro WH, Pizzi T 1955. Connective tissue reactions in normal and inmunized mice to a reticulotropic strain of Trypanosoma cruzi. J Infect Dis 96: 199-226.

Tanuri A, Almeida DF 1984. Izoenzyme variation in clones of Trypanosoma cruzi. An Acad Bras Cien 56: 117-118.

Tay J, Gutierrez M, Salazar PM, Castillo M, Ortega M 1973. Study of 6 strains of Mexican Trypanosoma cruzi. Rev
Invest Salud Publica 33: 67-76.

Tibayrenc 1995. Population genetics of parasitic protozoa and other microorganisms. Adv Parasitol 36: 48-115.

Tibayrenc M, Ayala F 1988. Isozyme variability in Trypanosoma cruzi, the agent of Chagas' disease: genetical, taxonomical and epidemiological significance. Evolution 42: 277 292.

Tibayrenc M, Ayala F 1991. Towards a population genetics of microorganisms: the clonal theory of parasite protozoa. Parasitol Today 7: 228-232.

Tibayrenc M, Brenière SF 1988. Trypanosoma cruzi: major clones rather than principal zymodemes. Mem Inst Oswaldo Cruz 83: 249-255.

Tibayrenc M, Miles MA 1983. A genetic comparison between Brazilian and Bolivian zymodemes of Trypanosoma cruzi. Trans R Soc Trop Med Hyg 77: 76-83.

Tibayrenc M, Hoffmann A, Poch O, Echalar L, Le Pont F, Lemesre JL, Desjeux P, Ayala FL 1986b. Additional data on Trypanosoma cruzi: izoenzymic strains encountered in Bolivian domestic transmission cycles. Trans $R$ Soc Trop Med Hyg 80: 442-447.

Tibayrenc M, Kjellberg F, Ayala FJ 1990. A clonal theory of parasites protozoa: the population structure of Entamoeba, Giardia, Leishmania, Naegleria, Plasmodium, Trichomonas, and Trypanosoma and their medical and taxonomical consequences. Proc Natl Acad Sci USA 87: 2414-2418.

Tibayrenc M, Neubauer K, Barnabé C, Guerrini F, Skarecky D, Ayala F 1993. Genetic characterization of six protozoa: parity betweem ramdom primer DNA typing and multilocus enzyme electrophoresis. Proc Natl Acad Sci USA 90: 13351339.

Tibayrenc M, Ward P, Moya A, Ayala FJ 1986a. Natural populations of the agent of Chagas' disease have a complex multiclonal structure. Proc Natl Acad Sci USA 83: 115-119.

Toyé PJ 1974. Isoenzyme variation in isolates of Trypanosoma cruzi. Trans R Soc Trop Med Hyg 68: 147.

Urdaneta L, Lal A, Barnabé C, Oury B, Golman I, Ayala F, Tibayrenc M 2001. Evidence for clonal propagation in natural isolates of Plasmodium falciparum from Venezuela. Proc Natl Acad Sci USA 98: 6725-6729.

Vago AR, Andrade LO, Leite AA, Reis DA, Macedo AM, Adad SJ, Tostes S, Moreira MCV, Filho GB, Pena SDJ 2000. Genetic characterization of Trypanosoma cruzi from tissues of patients with chronic Chagas disease. Am J Pathol 156: 1805-1809.

Vago AR, Macedo AM, Oliveira RP, Andrade LO, Chiari E, Galvão LM, Reis D, Pereira ME, Simpson AJ, Tostes S, Pena SD 1996. Kinetoplast DNA signatures of Trypanosoma cruzi strains obtained directly from infected tissues. Am J Pathol 149: 2153-2159.

Veloso VM, Tafuri WL, Lana M, Chiari E, Torres JA, Araújo FMG, Carneiro CM, Côrtes DF, Bahia MT 1996. Changes on the behaviour of Trypanosoma cruzi populations after infection for long periods of times in dogs. Mem Inst Oswaldo Cruz 91 (Suppl.): 220.

Vianna G 1911. Contribuição para o estudo da anatomia patológica da "Molestia de Carlos Chagas". Mem Inst Oswaldo Cruz 3: 276-294.

Watkins R 1966. Comparison of infections produced by two strains of Trypanosoma cruzi in mice. J Parasitol 52: 958961.

Weber JL 1990. Informativeness of human (dC-dA)n. (dG-dT)n polymorphisms. Genomics 7: 524-530.

Welsh J, McClelland M 1990. Fingerprinting genomes using PCR with arbitrry primers. Nuc Acids Res 18: 7213-7218. WHO-World Health Organization 1991. Control of Chagas 
Disease. Report of a WHO Expert Committee, WHO Technical Report Series no. 811, Geneva, 95 pp.

Willians JGK, Kubelik AR, Livak KJ, Rafalski JA, Tngey S 1990. DNA polymorphisms amplified by arbitrary primers are useful as genetic markers. Nuc Acids Res 18: 65316535.

Xu X, Peng M, Gang Z 2000. The direction of microsatellite mutations is dependent upon allele length. Nat Gen 24: 396-399.

Zingales B, Souto RP, Mangia RH, Lisboa CV, Campbell DA, Coura JR, Jansen A, Fernandes O 1998. Molecular epidemiology of American trypanosomiasis in Brazil based on dimorphisms of rRNA and mini-exon gene sequences. Inter J Parasitol 28: 105-112. 